\title{
Effects of alpha-linolenic acid vs. docosahexaenoic acid supply on the distribution of fatty acids among the rat cardiac subcellular membranes after a short- or long-term dietary exposure
} Amandine Brochot ${ }^{1,2}$, Marine Guinot ${ }^{1}$, Daniel Auchere ${ }^{1}$, Jean-Paul Macaire ${ }^{1}$, Pierre Weill ${ }^{2}$, Alain Grynberg ${ }^{1}$ and Delphine Rousseau-Ralliard ${ }^{* 1}$

\begin{abstract}
Address: ${ }^{1}$ Institut National de la Recherche Agronomique (INRA)-Université Paris-Sud 11, Unité Mixte de Recherche 1154, Lipides Membranaires et Régulation Fonctionnelle du Coeur et des Vaisseaux, Institut Fédératif de Recherche 141, Faculté de Pharmacie, Châtenay-Malabry, F-92296, France and ${ }^{2}$ Société Valorex, Combourtillé, France

Email: Amandine Brochot - amandinebrochot@gmail.com; Marine Guinot - marine.guinot@jouy.inra.fr; Daniel Auchere - not@valid.com; Jean-Paul Macaire - Jean-paul.macaire@jouy.inra.fr; Pierre Weill - Pierre.weill@valorex.com; Alain Grynberg - alain.grynberg@jouy.inra.fr; Delphine Rousseau-Ralliard* - delphine.rousseau@jouy.inra.fr

* Corresponding author
\end{abstract}

Published: II September 2009

Nutrition \& Metabolism 2009, 6:35 doi:10.1186/1743-7075-6-35
Received: 10 September 2009

Accepted: II September 2009

This article is available from: http://www.nutritionandmetabolism.com/content/6/1/35

(c) 2009 Brochot et al; licensee BioMed Central Ltd.

This is an Open Access article distributed under the terms of the Creative Commons Attribution License (http://creativecommons.org/licenses/by/2.0), which permits unrestricted use, distribution, and reproduction in any medium, provided the original work is properly cited.

\section{Correction}

A mistake has been noted in our recently published (25 March 2009) article [1]. This error appeared in the material and methods section, and concerns the content of Table 1.
An overlapping of the lines has occurred in the fatty acid profile section of the Table, due to an unfortunate insertion of the 22:2 n-6, a fatty acid that has nothing to do there. This returns any impossible understanding, particularly of the DHA supply and so intake. Table 1 has therefore been replaced here with a version that is both correct and also readable. 
Table I: Formulation and fatty acid composition of the experimental diets.

\begin{tabular}{|c|c|c|c|c|}
\hline & $\begin{array}{c}\text { CTL diet } \\
\text { g/kg of diet }\end{array}$ & $\begin{array}{l}\text { DHA diet } \\
\text { g/kg of diet }\end{array}$ & $\begin{array}{l}\text { ALA diet } \\
\text { g/kg of diet }\end{array}$ & $\begin{array}{c}\text { Extruded linseed flour }{ }^{5} \\
\mathrm{~g} / \mathrm{kg}\end{array}$ \\
\hline \multicolumn{5}{|l|}{ Basal mix I } \\
\hline Protein & & & & 200 \\
\hline Soy protein isolate ${ }^{2}$ & 170 & 170 & 147 & \\
\hline Glucides & & & & 110 \\
\hline Sucrose & 220 & 220 & 216 & 35 \\
\hline Cornstarch & 440 & 440 & 402 & \\
\hline Fibers (mucilages, ...) & & & & $17 \mid$ \\
\hline Cellulose & 20 & 20 & & 80 \\
\hline Minerals and other components & & & & 44 \\
\hline L-Cystine & 5 & 5 & 5 & \\
\hline Choline chloride & 5 & 5 & 5 & \\
\hline Mineral mixture ${ }^{3}$ & 50 & 50 & 48 & \\
\hline Vitamin mixture 3 & 10 & 10 & 10 & \\
\hline Extruded linseed flour ${ }^{4}$ & & & 122 & \\
\hline Lipids & & & & 280 \\
\hline hydrogenated coconut oil 5 & 15.2 & 15 & 11.3 & \\
\hline Cocoa butter 6 & 14.4 & 18 & 25.7 & \\
\hline Sunflower seed oil ${ }^{7}$ & 48 & 17 & 8.9 & \\
\hline Rapeseed oil 8 & 2.4 & 10 & & \\
\hline n-3 LCPUFA-rich oil ${ }^{9}$ & & 20 & & \\
\hline Humidity & & & & 80 \\
\hline Fatty acid composition 10 & $\%$ of total FA & $\%$ of total FA & $\%$ of total FA & $\%$ of total FA \\
\hline $14: 0$ & 4.7 & 4.6 & 3.5 & - \\
\hline 16:0 & 11.2 & 13.2 & 10.2 & 5.9 \\
\hline $18: 0$ & 8.5 & 11.4 & 8.4 & 2.9 \\
\hline $18: 1 \mathrm{n}-9$ & 21.7 & 17.5 & 17.0 & 17.3 \\
\hline $18: 2 n-6$ & 35.5 & 16.9 & 18.2 & 17.7 \\
\hline $18: 3 n-3$ & 0.6 & 23.3 & 1.4 & 55.1 \\
\hline $20: 5 n-3$ & - & - & 2.5 & - \\
\hline $22: 5 n-3$ & 0.3 & 0.5 & 0.5 & - \\
\hline $22: 6 n-3$ & - & - & 16.8 & - \\
\hline Total SFA & 40.6 & 40.7 & 39.8 & 9.1 \\
\hline Total MUFA & 22.7 & 18.4 & 18.0 & 18.1 \\
\hline Total PUFA & 36.8 & 40.8 & 42.2 & 72.8 \\
\hline Total n-6 PUFA & 36.0 & 17.5 & 20.5 & 17.7 \\
\hline Total n-3 PUFA & 0.7 & 23.4 & 21.7 & 55.1 \\
\hline$n-6 / n-3$ ratio & 50.6 & 0.7 & 0.9 & 0.3 \\
\hline PUFA/SFA ratio & 0.9 & 1.0 & 1.1 & 8.0 \\
\hline
\end{tabular}

\section{References}

I. Brochot A, Guinot M, Auchere D, Macaire JP, Weill P, Grynberg A, Rousseau-Ralliard D: Effects of alpha-linolenic acid vs. docosahexaenoic acid supply on thedistribution of fatty acids among the rat cardiac subcellular membranesafter a shortor long-term dietary exposure. Nutr Metab (Lond) 2009, 6:14.
Publish with Biomed Central and every scientist can read your work free of charge

"BioMed Central will be the most significant development for disseminating the results of biomedical research in our lifetime. "

Sir Paul Nurse, Cancer Research UK

Your research papers will be:

- available free of charge to the entire biomedical community

- peer reviewed and published immediately upon acceptance

- cited in PubMed and archived on PubMed Central

- yours - you keep the copyright

Submit your manuscript here:

http://www.biomedcentral.com/info/publishing_adv.asp
BioMedcentral 